\title{
FAKTOR-FAKTOR YANG MEMPENGARUHI KEPUTUSAN MAHASISWA MEMILIH FAKULTAS EKONOMI UNIVERSITAS ISLAM SUMATERA UTARA AL MUNAWAROH MEDAN
}

\author{
Wan Suryani \\ Paham Ginting
}

\begin{abstract}
In this globalization era competition among universities to attract students getting tougher. It is therefore universities should further strenghten its marketing strategy, so that they can attract new students to decide to study in the Faculty of Economics, Islamic University of North Sumatra, Medan. This study aims to determine what factors are influencing students in choosing education at Faculty of Economics, Islamic University of Al Monawaroh Medan North Sumatra. The number of samples used in this study were 83 people who are students at the Faculty of Economics, Islamic University of Al Munawaroh Medan North Sumatra. Sampling performed by the method of proportionate random sampling. Data were collected using questionnaires. Variables Measurement with Likert scale in 5 (five) scale. Prior to data collection, questionnaire were tested by validity and reliability test using 30 (thirty) respondents. The validity test using the Pearson correlation that correlate each item with total score of items and the reliability test using Cronbach Alpha. The result shows that factors must consider by the student when decided the Economy Faculty of UISU Al Munawaroh Medan are process, motivation, physical evidence, reference, cost, and location.
\end{abstract}

Keywords: process, motivation, physical evidence, refrence, cost, location

\section{PENDAHULUAN}

Pendidikan merupakan faktor pendukung yang memegang peranan yang sangat penting di segala sektor. Manusia membutuhkan pendidikan dalam kehidupannya. Pendidikan adalah usaha agar manusia dapat mengembangkan potensi dirinya melalui proses pembelajaran dan/atau cara lain yang dikenal oleh masyarakat.

Undang - Undang Dasar Negara Republik Indonesia Tahun 1945 pasal 31 ayat (1) menyebutkan bahwa setiap warga negara berhak mendapatkan pendidikan, dan ayat (3) menegaskan bahwa pemerintah mengusahakan dan menyelenggarakan satu sistem pendidikan nasional yang meningkatkan keimanan dan ketaqwaan serta akhlak mulia dalam rangka mencerdaskan kehidupan bangsa yang diatur dengan Undang-Undang. Undang-Undang Nomor 20 Tahun 2003 menyatakan bahwa

Wan Suryani, adalah Mahasiswa Sekolah Pascasarjana Universitas Sumatera Utara Paham Ginting, adalah Dosen Fakultas Ekonomi Universitas Sumatera Utara 
sistem Pendidikan Nasional memberikan dasar hukum untuk membangun pendidikan nasional dengan menerapkan prinsip Demokrasi, desentralisasi, otonomi, keadilan dan menjunjung tinggi hak asasi manusia. Penerapan ketentuan dalam undang-undang ini diharapkan dapat mendukung segala upaya untuk memecahkan masalah pendidikan, guna memberikan sumbangan yang signifikan terhadap masalah-masalah makro bangsa Indonesia.

Untuk itu, seluruh komponen bangsa wajib mencerdaskan kehidupan masyarakat yang merupakan tujuan bangsa Indonesia, sehingga memberikan kesempatan terhadap seluruh komponen masyarakat berhak untuk mendapatkan pendidikan yang lebih baik guna menciptakan sumber daya manusia yang berkualitas dan bertaqwa.

Dalam kerangka globalisasi, penyiapan pendidikan perlu disinergikan dengan tuntutan kompetisi. Karena itu dimensi daya saing dalam sumber daya manusia kelak menjadi faktor penting sehingga upaya memacu kualitas sumber daya manusia melalui pendidikan merupakan tuntutan yang harus dikedepankan. Untuk itu, lembaga pendidikan tinggi dituntut untuk mampu meningkatkan kualitas lulusannya agar mampu bersaing dengan tenaga baik dari dalam maupun luar negeri. Hal ini bukan hanya merupakan tanggung jawab perguruan tinggi negeri namun juga lembaga-lembaga pendidikan tinggi swasta, karena mengingat adanya batas daya tampung pada perguruan tinggi negeri. Dengan demikian, peranan pihak swasta di seluruh Indonesia sangat diharapkan dalam penciptaan kualitas sumber daya manusia yang handal.

Dalam upaya pengembangan lembaga pendidikan swasta, merupakan suatu tantangan untuk menghasilkan sumber daya manusia yang handal, berkualitas dan berdaya saing tinggi. Sebuah perguruan tinggi harus mampu mengetahui apa yang penting untuk para mahasiswa, memberikan informasi kepada para mahasiswa bahwa apa yang akan mereka berikan berguna untuk mahasiswa, dan kemudian memberikan apa yang telah mereka janjikan. Terdapat beberapa faktor yang menjadi daya tarik suatu perguruan tinggi baik secara internal maupun eksternal perguruan tinggi tersebut, sehingga mahasiswa memutuskan memilih perguruan tinggi tersebut untuk melanjutkan pendidikan.

Demikian juga halnya dengan Fakultas Ekonomi Universitas Islam Sumatera Utara Al Munawaroh Medan, merupakan Fakultas Ekonomi swasta di Sumatera. Pada awal berdirinya Fakultas Ekonomi mengasuh jurusan Ekonomi Umum dan Ekonomi Perusahaan dan perkembangan berikutnya tepatnya pada tahun 1980 jurusan Ekonomi Umum berubah menjadi jurusan Studi Pembangunan dan Ekonomi Perusahaan berubah menjadi jurusan Manajemen hingga saat ini. Kemudian pada tahun 1981 berdasarkan SK Menteri Pendidikan dan Kebudayaan RI No. 0170/0/1981 tanggal 22 Desember 1981, Fakultas Ekonomi memperoleh status terdaftar untuk jurusan Ilmu Ekonomi, Ekonomi Manajemen dan Studi Pembangunan. Selanjutnya berdasarkan SK Menteri Pendidikan dan Kebudayaan RI No. 0339/1985 tangaal 29 Juli 1985, Ilmu Ekonomi Studi Pembangunan dan Manajemen memperoleh status disamakan.

Berangkat dari uraian di atas, maka dapat dirumuskan masalah penelitian adalah "Faktor - faktor apa saja yang mempengaruhi keputusan mahasiswa dalam menempuh pendidikan pada fakultas ekonomi Universitas Islam Sumatera Utara Medan". 
Adapun tujuan dari penelitian ini adalah untuk mengetahui faktor-faktor yang mempengaruhi mahasiswa memilih Fakultas Ekonomi Universitas Islam Sumatera Utara Al Munawaroh Medan.

\section{Penelitian Terdahulu}

Penelitian oleh Mardiah (2001) dengan judul "Analisis Faktor-Faktor Yang Menentukan Pilihan Mahasiswa Dalam Menempuh Pendidikan Program Pasca Sarjana Di Institut Teknologi Sepuluh Nopember Surabaya", menetapkan sampel sebanyak 200 responden dengan cara Stratified Random Sampling dari populasi sebanyak 752 mahasiswa. Dalam penelitian ini terdapat 46 faktor yang dianalisis dengan menggunakan analisis faktor. Dari penelitian ini diperoleh beberapa faktor yang mempengaruhi pilihan mahasiswa dalam menempuh pendidikan yaitu : faktor proses, faktor personal, faktor physical evidence, faktor referensi, faktor motivasi, faktor aktivitas mahasiswa, faktor lokasi, faktor biaya, faktor status sosial, faktor alumni.

\section{TINJAUAN PUSTAKA \\ Pengertian Perilaku Konsumen}

Schiffman and Kanuk (2010 : 437) mendefinisikan perilaku konsumen sebagai berikut: "The term consumer behavior can bedefed as the behavior that consumers display in searching for purchasing, using, evaluating, and disposing of products, service and ideas and which they expect will satisfy their needs". (Istilah perilaku konsumen diartikan sebagai perilaku yang diperlihatkan konsumen untuk mencari, membeli, menggunakan, mengevaluasi, dan menghabiskan produk dan jasa yang mereka harapkan akan memuaskan kebutuhan mereka).

\section{Faktor - Faktor Yang Mempengaruhi Keputusan Konsumen}

Kotler dan Amstrong (2003:189) menyatakan "Consumer purchases are influence strongly by cultural, social, personal, and psichological characteristic". (Menurut Kotler dan Amstrong (2003:200), faktor-faktor yang mempengaruhi keputusan konsomen untuk membeli terdiri dari) :

1. Faktor budaya, yaitu penentu keinginan dan perilaku yang mendasari yang terdiri dari kumpulan nilai, preferensi dan perilaku menunjukkan preferensi produk dan merek yang berbeda dalam banyak hal.

2. Faktor sosial, yaitu dapat berasal dari kelompok acuan merupakan semua kelompok yang mempengaruhi langsung (tatap muka) atau tidak terhadap sikap atau perilaku seseorang, sedangkan berasal dari keluarga merupakan organisasi pembelian yang paling penting dalam masyarakat, dan ia telah menjadi objek penelitian yang luas.

3. Faktor pribadi, yaitu terdiri dari usia dan tahap siklus hidup konsumsi yang dibentuk oleh siklus hidup keluarga, pemasar sering memilih kelompok berdasarkan siklus hidup sebagai pasar sasaran.

4. Faktor psikologis, yaitu motivasi dan pengetahuan sesroang konsumen yang timbul dari pengalamannya. 


\section{Proses pengambilan keputusan membeli pada konsumen}

Menurut Kotler dan Keller (2009:184), Proses pengambilan keputusan membeli pada konsumen dapat dipengaruhi oleh berbagai faktor, baik yang bersifat individual (internal) maupun yang berasal dari lingkungan (eksternal):

1. Faktor individual (internal)

a. Sumber daya konsumen Waktu, uang dan perhatian merupakan sumber daya yang dimiliki konsumen yang digunakan dalam setiap situasi pengambilan keputusan.

b. Keterlibatan dan motivasi

Keterlibatan merupakan tingkat dari kepentingan atau ketertarikan personal yang ditimbulkan oleh stimulus dalam situasi tertentu. Terhadap tingkat keterlibatan yang hadir, konsumen di motivasi untuk bertindak dengan pertimbangan untuk meminimalkan resiko dan untuk memaksimalkan keutungan yang didapat dari penggunaan dan pembelian.

c. Pengetahuan

Pengetahuan konsumen terdiri dari informasi yang disimpan di dalam ingatan. Informasi yang dimiliki konsumen mengenai produk akan sangat mempengaruhi pola pembelian mereka.

d. Sikap

Sikap didefinisikan sebagai evaluasi menyeluruh, intensitas, dukungan dan kepercayaan adalah sifat penting dari sikap. Pencarian informasi dan evaluasi yang luas atas pelbagai kemungkinan akan menghasilkan pembentukan suatu sikap terhadap alternatif-alternatif yang dipertimbangkan.

e. Kepribadian

Kepribadian diartikan sebagai respon yang konsisten terhadap stimulus lingkungan. Kepribadian seseorang akan menentukan bagaimana seseorang mengkonsumsi suatu produk.

f. Gaya hidup

Gaya hidup diartikan sebagai pola dimana orang hidup dan menghabiskan waktu serta uang. Gaya hidup yang dianut seseorang juga menentukan dalam pemilihan serta keputusan pembelian sebuah produk.

g. Demografi

Karakteristik demografi seperti usia, pendapatan dan pendidikan juga membedakan bagaimana seseorang terlibat dalam pengambilan keputusan konsumen.

\section{Faktor lingkungan (eksternal)}

a. Budaya

Budaya dalam perilaku konsumen mengacu pada nilai, gagasan, artefak, dan simbol-simbol lain yang bermakna yang membantu individu untuk berkomunikasi, melakukan penafsiran dan evaluasi sebagai anggota masyarakat. Perbedaan budaya juga menentukan jenis produk yang dipilih untuk dikonsumsi. 
b. Kelas sosial

Kelas sosial adalah pembagian di dalam masyarakat yang terdiri dari individu-individu yang berbagi nilai, minat, dan perilaku yang sama. Status kelas sosial menghasilkan bentuk-bentuk perilaku konsumen yang berbeda

c. Pengaruh kelompok dan keluarga

Keluarga adalah kelompok yang terdiri atas dua orang atau lebih yang dihubungkan melalui darah, perkawinan atau adopsi dan tinggal bersama. Keputusan pembelian individu sangat mungkin dipengaruhi oleh anggota lain dalam keluarganya. Kelompok juga berpengaruh dalam memberikan referensi mengenai suatu produk, toko dsb.

\section{Pemasaran Jasa}

Jasa sering dipandang sebagai fenomena yang rumit. Kata jasa itu sendiri mempunyai banyak arti, dari mulai pelayanan personal (personal service) sampai jasa sebagai suatu produk. Sejauh ini sudah banyak pakar pemasaran jasa yang telah berusaha mendefinisikan pengertian jasa.

Berdasarkan ensiklopedia Indonesia yang dikutip oleh Fuad Ihsan dalam bentuk dasar-dasar kependidikan (2003:7), pendidikan dapat diartikan sebagai proses dimana seseorang mengembankan kemampuan sikap dan bentuk-bentuk tingkah laku lainnya di dalam masyarakat dimana ia hidup, proses sosial dimana orang dihadapkan pada pengaruh lingkungan yang terpilih dan terkontrol.

Rangkuti (2003) menyatakan bahwa "pemasaran jasa tidak sama dengan pemasaran produk. Pemasaran jasa lebih bersifat intangible dan inmaterial karena produkya tidak kasat mata dan tidak dapat diraba, produk jasa dilakukan disaat konsumen berhadapan dengan petugas sehingga pengawasan kualitasnya dilakukan dengan segera, interaksi antara konsumen dan pengawas adalah penting untuk mewujudkan produk yang dibentuk".

\section{Karakteristik Dan Klasifikasi Jasa}

Produk jasa memiliki karakteristik yang berbeda dengan barang (produk fisik). Griffin (dalam Lupiyoadi, 2008:7) di antaranya menyebutkan karakteristik tersebut sebagai berikut :

1. tidak berwujud (Intangibility), jasa tidak dapat dilihat, dirasa, diraba, didengar, atau dicium sebelum jasa itu dibeli. Nilai penting dari hal ini adalah nilai tidak berwujud yang dialami konsumen dalam bentuk kenikmatan, kepuasan, atau rasa aman.

2. Unstorability, jasa tidak mengenal persediaan atau penyimpanan dari produk yang dihasilkan. Karakteristik ini juga tidak dapat dipisahkan (unseparability), mengingat pada umumnya jasa dihasilkan dan dikonsumsi pada saat bersamaan.

3. Customization, jasa juga sering kali didesain khusus untuk kebutuhan pelanggan.

\section{Kerangka Konseptual}

Dalam upaya pengembangan lembaga pendidikan swasta, merupakan suatu tantangan untuk menghasilkan sumber daya manusia yang handal, berkualitas dan berdaya saing tinggi sekaligus juga harus mempertahankan eksistensi perguran 
tinggi di tengah banyaknya muncul perguruan tinggi pesaing. Sebuah perguruan tinggi harus mampu mengetahui apa yang penting untuk para mahasiswa, memberikan informasi kepada para mahasiswa bahwa apa yang akan mereka berikan berguna untuk mahasiswa, dan kemudian memberikan apa yang telah mereka janjikan, sehingga perguruan tinggi tersebut tidak ditinggalkan dan terpaksa harus menutup perguran tinggi tersebut.

Terdapat beberapa faktor yang menjadi daya tarik suatu perguruan tinggi baik secara internal maupun eksternal perguruan tinggi sehingga mahasiswa memutuskan memilih perguruan tinggi tersebut untuk melanjutkan pendidikan. Tjiptono (2005:32) menyatakan bahwa " stimulus mempengaruhi kebutuhan seseorang untuk membeli akan produk dan jasa tertentu". Kebutuhan untuk membeli produk atau jasa tersebut dipengaruhi oleh "shortages (kebutuhan yang timbul karena ketidakpuasan pelanggan terhadap produk dan jasa saat ini).

Mowen dan Minor (2002:102) menyatakan bahwa "tingkat keterlibatan konsumen dalam suatu pembelian dipengaruhi oleh kepentingan personal yang dirasakan ditimbulkan oleh stimulus, produk, harga, promosi, lokasi”. Lamb (2001) menyatakan bahwa "tingkat keterlibatan dalam pembelian tergantung pada lima faktor yaitu : pengalaman sebelumnya, minat, resiko, situasi dan pandangan sosial".

Terkait dengan keputusan mahasiswa dalam memilih Fakultas Ekonomi Universitas Islam Sumatera Utara Al munawaroh (FE.UISU Al Munawaroh), juga dipengaruhi beberapa stimulus dan juga kebutuhan akan pendidikan untuk kebaikan masa depan mereka. Memang banyak perguruan tinggi yang merupakan pesaing juga menawarkan hal-hal yang hampir sama atau mungkin sama dengan apa yang ditawarkan oleh Fakultas Ekonomi Universitas Islam Sumatera Utara Al Munawaroh. Namun ada beberapa alasan ataupun faktor-faktor yang mempengaruhi mengapa mahasiswa memutuskan untuk memilih Fakultas Ekonomi Universitas Islam Sumatera Utara Al Munawaroh Medan.

Mahasiswa akan melihat faktor-faktor yang menguntungkan dan sekaligus juga faktor-faktor yang bisa merugikan jika mereka memilih perguruan tinggi tertentu untuk tempat belajar. Pemahaman pengambilan keputusan mahasiswa sangat penting bagi suatu perguruan tinggi, karena berhasil tidaknya perguruan tinggi menarik mahaiswa tergantung faktor-faktor apa yang menjadi pendorong atau membuat ada keinginan dari pada mahasiswa untuk memilih perguruan tinggi tersebut.

Adapun faktor-faktor yang dianggap menjadi daya tarik mahasiswa untuk melanjutkan studi di Fakultas Ekonomi Universitas Islam Sumatera Utara dipengaruhi oleh beberapa faktor : Proses, Physical evidence, Referensi, Motivasi, akreditasi, aktivitas mahasiswa, Biaya, Latarbelakang sosial, Reputasi, Lokasi, dan Promosi. Dengan pertimbangan ini perguruan tinggi Fakultas Ekonomi Universitas Islam Sumatera Utara Al Munawaroh akan membuat kebijakan dengan memperhatikan kepada kekuatan, kelemahan, tantangan dan ancaman yang mungkin terjadi. Sehingga apa yang menjadi harapan perguruan tinggi menghasilkan alumni yang berkualitas sekaligus tetap eksis sebagai suatu bisnis di dunia pendidikan dapat tercapai. 


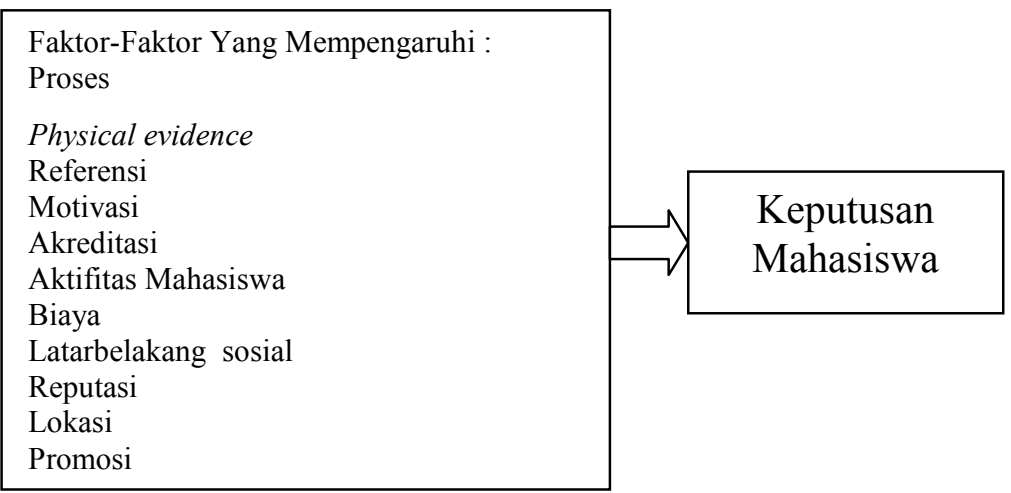

Gambar 1. Kerangka Konseptual

\section{METODE}

Penelitian ini disusun sebagai penelitian deduktif yakni metode berpikir yang menerapkan hal-hal yang umum terlebih dahulu untuk seterusnya dihubungkan dalam bagian-bagiannya yang khusus. Mencari dan mengumpulkan data yang ada di lapangan dengan tujuan untuk mengetahui faktor-faktor apa saja yang secara dominan mempengaruhi mahasiswa memilih fakultas ekonomi Universitas Islam Sumatera Utara.

Adapun sifat penelitian adalah explanotary factor analysis bila banyaknya faktor yang akan terbentuk tidak ditentukan terlebih dahulu (Sugiyono, 2009:109). Sugiyono (2010:114) menjelaskan bahwa, Populasi dalam penelitian ini adalah seluruh mahasiswa yang menempuh pendidikan di Fakultas Ekonomi Universitas Islam Sumatera Utara Al Munawaroh tahun 2009 sampai dengan 2012. Jumlah populasi sebanyak 460 orang mahasiswa yang terdiri dari tiga program studi yang dapat dilihat pada Tabel 3.1 berikut ini.

Tabel 1

Jumlah Populasi Penelitian

\begin{tabular}{|l|l|l|l|l|l|l|}
\hline No & Program Studi & $\mathbf{2 0 0 9}$ & $\mathbf{2 0 1 0}$ & $\mathbf{2 0 1 1}$ & $\mathbf{2 0 1 2}$ & Jumlah \\
\hline 1 & Manajemen S1 & 69 & 55 & 62 & 65 & 251 \\
\hline 2 & Akuntansi S1 & 43 & 50 & 40 & 45 & 178 \\
\hline 3 & $\begin{array}{l}\text { Ekonomi Pembangunan } \\
\text { S1 }\end{array}$ & 10 & 13 & 5 & 3 & 31 \\
\hline & Jumlah & 122 & 118 & 107 & 112 & 460 \\
\hline
\end{tabular}

Sumber : Biro administrasi FE.UISU Al Munawaroh Medan

\section{Definisi operasionalisasi variabel}

Proses, kegiatan yang menunjukkan bagaimana pelayanan diberikan kepada mahasiswa selama menjalankan pendidikan. Terdiri dari variabel :Kemampuan dosen, Hubungan dosen dengan mahasiswakesesuaian kurikulum; jangka waktu penyelesaian. 
Physical Evidence, keadaan atau bentuk fisik dari Perguruan Tinggi tersebut. Terdiri dari variabel : keadaan gedung; pusat computer; laboratorium; fasilitas mengajar.

Referensi, sumber acuan bagi mahasiswa dalam mencari informasi awal sebelum memutuskan memilih Perguruan Tinggi. Terdiri dari variabel : informasi dari mahasiswa yang lama; informasi dari keluarga; referensi dari perusahaan.

Motivasi, sejumlah proses yang bersifat internal dan eksternal bagi seorang individu yang menyebabkan timbulnya sikap antusiasme dan persistensi dalam hal melaksanakan kegiatan-kegiatan tertentu. Terdiri dari variabel : meningkatkan pengetahuan, ingin berprestasi; keinginan orang tua.

Akreditasi, kegiatan yang dilakukan untuk menentukan kelayakan program dan satuan pendidikan pada jalur pendidikan fomal maupun non formal pada setiap jenjang dan jenis pendidikan berdasarkan criteria yang bersifat terbuka. Terdiri dari variabel : peringkat yang diberikan BAN-PT, tuntutan pekerjaan, jumlah penelitian yang dilakukan kampus.

Aktivitas Mahasiawa, wadah untuk mengembangkan minat, bakat dan keahlian mahasiswa, baik yang ada ditingkat program studi, jurusan maupun Universitas. Terdiri dari variabel : adanya UKM (Unit Kegiatan Mahasiswa), adanya organisasi kemahasiswaan, adanya BEM (Badan Eksekutif Mahasiswa).

Biaya, segala pengorbanan financial yang dikeluarkan mahasiswa menempuh pendidikan pada lembaga pilihannya. Terdiri dari variabel : uang pendaftaran; uang kuliah; biaya hidup.

Latar belakang sosial ekonomi, hal-hal yang melatarbelakangi keberadaan sosial ekonomi mahasiswa. Terdiri dari variabel : tingkat pendapatan orang tua; pendidikan orang tua; pekerjaan orang tua.

Reputasi, persepsi masyarakat secara umum tentang keberadaan lembaga pendidikan. Terdiri dari variabel : pengakuan ijazah pada instansi pendidikan lain; dikenal secara umum sebagai lembaga pendidikan yang baik; lulusan yang mampu menerapkan hukum/prinsip syariah dalam kehidupannya.

Lokasi , faktor-faktor yang berkaitan dengan letak lembaga pendidikan secara geografis. Terdiri dari variabel : letak ditengah kota; kemudahan transportasi; terletak di jalan besar.

Promosi, upaya dari pihak lembaga pendidikan (FE.UISU Al Munawaroh) untuk memberikan informasi kepada mahasiswa agar mengetahui keberadaan produknya. Terdiri dari variabel : penggunaan iklan di media masa dan elektronik, penggunaan brosur sebagai media informasi; penggunaan web site.

\section{Metode Analisis Data}

Metode Analisis Faktor adalah teknik statistik yang digunakan untuk mengidentifikasikan sejumlah faktor yang dapat mewakili hubungan antar sejumlah variabel yang sangat berhubungan. Analisis ini juga merupakan teknik reduksi data yang dapat digunakan untuk mengubah (menyederhanakan) sejumlah variabel yang saling berkorelasi menjadi kelompok-kelompok variabel yang lebih kecil, yang disebut sebagai faktor. Proses analisis faktor dilakukan dengan ekstrasi variabel hingga menjadi satu atau beberapa faktor (dengan bantuan SPSS). Perhitungan dalam tahap ini nantinya akan menggunakan tabel perhitungan nilai komunal (communalities) dan nilal total variansi (total variance explained). 
Selanjutnya hasil perhitungan yang ditunjukkan dalam nilai total variansi (eigenvalues) akan digunakan sebagai dasar penentuan jumlah faktor yang akan digunakan. Penentuan jumlah faktor ini didasarkan pada banyaknya faktor yang memiliki nilai eigen (eigenvalues) lebih dari satu.

$\mathrm{X}_{\mathrm{i}}=\mathrm{Aij} \cdot \mathrm{F} 1+\mathrm{Ai} 2 \cdot \mathrm{F} 2+\ldots \ldots .+\mathrm{Aim} \cdot \mathrm{Fm}+$ bi.Ui

Dimana :

$\mathrm{j}=1,2, \ldots . ., \mathrm{n}$

$\mathrm{j}=1,2, \ldots . ., \mathrm{m}$

$\mathrm{Xi}=$ peubah ke- $\mathrm{i}$

Aij $=$ koefisien faktor kesamaan

$\mathrm{Fj}$ = faktor kesamaan ke-j

$\mathrm{bi}=$ koefisien faktor unik ke-i

$\mathrm{Ui}=$ faktor unik ke-i

Tahapan analisis yang dilakukan dalam analisis faktor adalah sebagai berikut

1. Menentukan jumlah kasus yang diteliti, yaitu sebanyak $\mathrm{m}$ buah, dan juga menentukan jumlah $\mathrm{n}$ peubah yang akan diobservasi

2. Membuat matriks data awal dengan ukuran matriks (mxn)

3. Menstandarisasikan matriks data awal ke dalam bentuk baku atau bentuk normal (data dinormalisasikan), dengan menggunakan persamaan2

$$
\mathrm{Xn}=\frac{\mathrm{Xij}-\mathrm{Xr}}{\sigma}
$$

dimana,

$\mathrm{Xn}=$ Nilai data normal

$\mathrm{Xij}=$ Nilai data

$\mathrm{Xr}=$ Nilai rata-rata

$\sigma=$ Standar deviasi

c. Tehnik dan berbentuk Korelasi

Penghitungan ini dimaksudkan untuk melihat korelasi antara beberapa variabel bebas, terutama untuk mendeteksi adanya collinearity dari beberapa variabel bebas. Hal ini diperhitungkan, mengingat jumlah variabel bebas yang cukup banyak dalam penelitian ini dan berbentuk variabel diskrit ( $\mathrm{ya}=0$ dan tidak $=1$ ), serta pengukuran skalanya dalam bentuk nominal. Asumsi korelasi yang meliputi

a. Besar korelasi antar variable independent harus cukup kuat atau di atas 0,3.

b. Besar korelasi parsial yaitu korelasi antar dua variabel dengan menganggap tetap variabel lain, justru harus kecil atau mendekati nol.

c. Uji hipotesis bahwa matriks korelasi adalah bukan matriks identitas, dengan menggunakan Barlett's Test of Sphericity. Nilai signifikasi yang diperoleh Barlett's Test of Sphericity harus lebih kecil dari 0,05 (sig < 0.05)

d. Asumsi ukuran kecukupan sampling yang diuji dengan Kaiser-Meyer-Olkin (KMO).

KMO merupakan indeks untuk membandingkan besarnya koefisien korelasi amatan dengan koefisien parsial, yang berarti bahwa besar koefisien korelasi keseluruhan variabel pada matriks korelasi harus 
signifikan di antara paling sedikit beberapa variabel. Angka KMO disyaratkan harus lebih dari 0.5 .

$\mathrm{KMO}=\frac{\sum_{i=1}^{p} \sum_{j=1}^{p} r_{i j}^{2}}{\sum_{i=1}^{p} \sum_{j=1}^{p} r_{i j}^{2}+\sum_{i=1}^{p} \sum_{j=1}^{p} a_{i j}^{2}}$

dimana :

rij $=$ koefisien korelasi sederhana antara peubah $\mathrm{i}$ dan $\mathrm{j}$

aij $=$ koefisien korelasi parsial antara peubah $i$ dan $j$

nilai KMO akan meningkat bila jumlah ukuran sample bertambah, rata-rata koefisien korelasi bertambah, dan jumlah variabel bertambah atau jumlah faktor berkurang.

\section{PEMBAHASAN}

\section{Hasil Analisis Data}

Dari hasil output program SPSS untuk data 35 pertanyaan yang dijawab oleh 83 responden, dalam kuesioner, ternyata didapatkan hasil sebagai berikut :

nilai KMO sebesar 0,558 sehingga analisis faktor layak dilakukan dengan kategori baik, sedangkan hasil perhitungan anti-image correlation pada masingmasing variabel terlihat nilai koefisien anti-image correlation lebih besar dari 0,500. Sehingga analisis faktor layak digunakan.

\section{MSA (Measure of Sampling Adequacy)}

Anti image correlation. Data mengenai variabel yang berasal dari jawaban dari 83 responden kemudian dianalisis pada anti image correlation, menunjukkan kriteria angka MSA diatas 0,5. yang berarti variabel masih bisa diprediksi untuk dianalisis lebih lanjut (Santoso, 2002:101). Jika dilihat dari analisis di atas, maka variable-variabel yang memiliki MSA $<0,5$ adalah variable V1,V5, V16, V17, V21, V22, V27, V29, V30, dan V32. Sisanya memiliki MSA > 0,5. Untuk hasil yang lebih akurat, perlu dilakukan analisis ulang dengan cara yang sama.

\section{KMO and Bartlett's Test}

\begin{tabular}{|c|c|}
\hline $\begin{array}{l}\text { Kaiser-Meyer-Olkin Measure of Sampling Adequacy. } \\
\text { Bartl Approx. Chi-Square } \\
\text { ett's Df } \\
\text { Test Sig. } \\
\text { of } \quad \\
\text { Sphe } \\
\text { ricity }\end{array}$ & $\begin{array}{r}.634 \\
747.896 \\
120\end{array}$ \\
\hline
\end{tabular}

Nilai KMO (measure of sampling adequacy) untuk analisis yang kedua 
menjadi sebesar 0,634. Dari nilai semula 0.558, dengan demikian dapat diketahui nilai KMO MSA mengalami kenaikan setelah kita membuang variable-variabel yang tidak memenuhi persyaratan.

Nilai communalities tertinggi adalah variabel 31 sebesar 0.909 , artinya kemudahan transportasi dapat menjelaskan $90.9 \%$ varians faktor yang terbentuk. Sebaliknya nilai communalities yang terendah adalah variabel 9 informasi dari mahasiswa lama sebesar 0.609, artinya informasi dari mahasiswa lama dapat menjelaskan $60.9 \%$ varians faktor yang terbentuk. demikian dengan variabelvariabel yang lainnya.

\section{Communalities}

\begin{tabular}{|l|r|r|}
\hline & Initial & Extraction \\
\hline V2 & 1.000 & .822 \\
V3 & 1.000 & .810 \\
V4 & 1.000 & .844 \\
V5 & 1.000 & .862 \\
V6 & 1.000 & .854 \\
V7 & 1.000 & .870 \\
V8 & 1.000 & .766 \\
V9 & 1.000 & .609 \\
V10 & 1.000 & .827 \\
V11 & 1.000 & .864 \\
V12 & 1.000 & .888 \\
V13 & 1.000 & .826 \\
V14 & 1.000 & .824 \\
V23 & 1.000 & .767 \\
V28 & 1.000 & .654 \\
V31 & 1.000 & .909 \\
\hline
\end{tabular}

Extraction Method: Principal Component Analysis.

Pada Tabel Total Variance Explained, nilai eigenvalues ditunjukkan untuk masing-masing faktor yang semula tiga puluh lima variable asli, setelah ada variabel-variabel yang terbuang menjadi enambelas variabel. Nilai eigenvalues yang lebih besar dari satu terdiri dari enam faktor yang secara bersama dapat menjelaskan varians total sebesar $81.216 \%$.

Enambelas variabel diekstrak menjadi 6 (enam) faktor, maka :

a. Varians faktor pertama adalah $22.451 \%$

b. Varians faktor kedua adalah $3.093 / 16 \times 100 \%=19.333 \%$

c. Varians faktor ketiga adalah $1.932 / 16 \times 100 \%=12.074 \%$

d. Varians faktor keempat adalah 1.788/16 x $100 \%=11.173 \%$

e. Varians faktor kelima adalah $1.575 / 16 \times 100 \%=9.846 \%$ 
f. Varians faktor keenam adalah $1.015 / 16 \times 100 \%=6.341 \%$

\section{Rotasi Faktor}

Berdasarkan hasil total initial eigenvalues menunjukkan terdapat 6 faktor yang terbentuk dalam kaitannya dengan keputusan mahasiswa. Dari hasil pemetaan dengan menggunakan component matrix terlihat seluruh variabel pada 6 faktor, berikut adalah hasilnya :

Ada beberapa faktor-faktor yang terbentuk berdasarkan Tabel diatas, pengelompokan suatu variabel menjadi anggota suatu faktor di dasarkan loading faktor variabel terbesar yang berada pada enam faktor. Pada variabel sebelas (V11) termasuk anggota faktor 2 (dua) karena memiliki loading factor (0.900) pada faktor ke 2 (dua). Dengan demikian dapat dikatakan variabel V11 dapat dimasukkan sebagai komponen faktor 2 (dua), demikian seterusnya.

\section{Hasil Analisis}

Terdapat enam faktor yang terbentuk terhadap faktor-faktor yang mempengaruhi mahasiswa memilih Fakultas Ekonomi Universitas Islam Sumatera Utara Al Munawaroh Medan, dengan komulatif variasi sebesar $81.216 \%$ yaitu :

1. Faktor 1 proses

Faktor pertama dengan eigenvalues sebesar 3.592 variabel yang mempengaruhi faktor 1 adalah :. Hubungan dosen dengan mahasiswa (V2),. Kesesuaian kurikulum (V3), jangka waktu penyelesaian (V4). Ini berarti faktor pertama atau proses mempengaruhi keputusan mahasiswa dalam memilih Fakultas Ekonomi Universitas Islam Sumatera Utara Al Munawaroh Medan.

2. Faktor 2 motivasi

Faktor kedua dengan eigenvalues sebesar 3.093 variabel yang mempengaruhi faktor 2 adalah : referensi dari perusahaan (V11), meningkatkan pengetahuan (V12), ingin berprestasi (V13). Ini berarti faktor motivasi merupakan faktor kedua yang mempengaruhi keputusan mahasiswa dalam memilih Fakultas Ekonomi Universitas Islam Sumatera Utara Al Munawaroh Medan.

3. Faktor 3 physical evidence

Faktor ketiga dengan eigenvalues sebesar 1.932 variabel yang mempengaruhi faktor 3 : keadaan gedung (V5), pusat komputer (V6), laboratorium (V7), Nilai varian sebesar 12.074 berarti faktor 3 mempengaruhi keputusan mahasiswa dalam memilih Fakultas Ekonomi Universitas Islam Sumatera Utara Al Munawaroh Medan sebesar $12.074 \%$.

4. Faktor 4 referensi

Faktor keempat dengan eigenvalues sebesar 1.788 variabel yang mempengaruhi faktor 4 adalah: penggunaan website (V8), kemudahan transportasi (V9), dikenal secara umum lembaga pendidikan yang baik (V10), . Nilai varian sebesar 11.173 berarti faktor keempat atau referensi mempengaruhi keputusan mahasiswa dalam memilih Fakultas Ekonomi Universitas Islam Sumatera Utara Al Munawaroh Medan sebesar $11.173 \%$.

5. Faktor 5 biaya

Faktor kelima dengan eigenvalues sebesar 1.575 variabel yang mempengaruhi faktor 5 adalah : keinginan orang tua (V14). Biaya hidup (V23) Nilai varian sebesar 9.846 berarti faktor kelima dipahami mempengaruhi keputusan mahasiswa 
dalam memilih Fakultas Ekonomi Universitas Islam Sumatera Utara Al Munawaroh Medan sebesar $9.846 \%$.

6. Faktor 6 lokasi

Faktor keenam dengan eigenvalues sebesar 1.015 variabel yang mempengaruhi faktor 6 adalah : kemudahan transportasi (V32) . Nilai varian sebesar 6.341 berarti faktor keenam dipahami mempengaruhi keputusan mahasiswa dalam memilih Fakultas Ekonomi Universitas Islam Sumatera Utara Al Munawaroh Medan sebesar $6.341 \%$.

\section{KESIMPULAN}

\section{Kesimpulan}

Dari hasil penelitian dan pembahasan, dapat disimpulkan terdapat enam faktor yang mempengaruhi mahasiswa dalam memilih Fakultas Ekonomi Universitas Islam Sumatera Utara Al Munawaroh Medan, yaitu : Faktor proses, faktor motivasi, faktor physical evidence, faktor referensi, faktor biaya, dan faktor lokasi.

\section{Saran}

Untuk meningkatkan keputusan mahasiswa dalam menempuh pendidikan, maka dibuat beberapa saran :

1. Ditinjau dari faktor proses, pihak yayasan harus mampu meningkatkan pelayanan kepada mahasiswa misalnya dengan menyusun bahan materi kuliah dan kurikulum yang jelas dan bermutu kepada mahasiswanya, sehingga mahasiswa Fakultas Ekonomi Universitas Islam Sumatera Utara Al Munawaroh Medan dapat menyelesaikan pendidikan S1 dengan sistematis dan sesuai dengan aturan yang diterapkan. Selain itu, pihak Fakultas Ekonomi Universitas Islam Sumatera Utara Al Munawaroh Medan juga harus terus meningkatkan hubungan yang harmonis antara dosen dengan mahasiswa misalnya dengan mengadakan beribadah bersama pada hari libur atau hari besar keagamaan. Hal ini akan mampu meningkatkan prestasi mahasiswa di bidang akademis, dan juga akan membantu dosen lebih bersemangat dalam memberikan pengajaran.

2. Ditinjau dari faktor motivasi, pihak yayasan harus mampu menjaga kualitas pendidikan Fakultas Ekonomi Universitas Islam Sumatera Utara Al Munawaroh Medan, dengan cara melakukan rekrutment terhadap dosen yang berkualitas dan mampu untuk menyalurkan pengetahuannya kepada mahasiswa. Hal ini perlu diperhatikan karena saat ini Fakultas Ekonomi Universitas Islam Sumatera Utara Al Munawaroh Medan sudah memiliki brands yang cukup baik di kalangan masyarakat kota medan. Hal ini juga akan membuat para orang tua lebih menodorong anaknya untuk melanjutkan pendidikan di Fakultas Ekonomi Universitas Islam Sumatera Utara Al Munawaroh Medan.

3. Ditinjau dari faktor physical evidence pihak yayasan harus mampu meningkatkan sarana dan prasarana di lingkungan kampus, seperti sarana olahraga, kebersihan gedung, ketersediaan ruangan lab komputer, dan 
sebagainya. Hal ini akan mempengaruhi motivasi seorang mahasiswa untuk menyalurkan prestasinya, baik akademis maupun non akademis.

4. Ditinjau dari Faktor referensi, pihak yayasan harus terus menjaga dan meningkatkan kredibilitas Fakultas Ekonomi Universitas Islam Sumatera Utara Al Munawaroh Medan, seperti ikut berprestasi dalam kompetisi atau turnamen yang bersifat akademis dan non akademis. Hal ini perlu diperhatikan karena brands dari Fakultas Ekonomi Universitas Islam Sumatera Utara Al Munawaroh Medan akan ditentukan dari hal tersebut. Selain itu, para alumni juga harus menjaga nama baik Fakultas Ekonomi Universitas Islam Sumatera Utara Al Munawaroh Medan sehingga persepsi masyarakat terhadap Fakultas Ekonomi Universitas Islam Sumatera Utara Al Munawaroh Medan dapat tetap terjaga dengan baik. oleh karena itu, perlu komunitas alumni juga harus dapat berperan dalam memberikan kegiatan yang berguna bagi masyarakat umum, seperti gerakan sosial.

5. Ditinjau dari Faktor biaya, pihak yayasan juga harus mampu memberikan harga yang terjangkau untuk uang kuliah. Selain itu, pihak Fakultas Ekonomi Universitas Islam Sumatera Utara Al Munawaroh Medan juga harus mampu menyediakan beasiswa kepada mahasiswa yang berprestasi baik di bidang akademis maupun non akademis. Hal ini perlu diperhatikan karena dengan pemberian reward kepada mahasiswa sehingga mahasiswa dapat lebih berprestasi. Selain itu, pihak Fakultas Ekonomi Universitas Islam Sumatera Utara Al Munawaroh Medan juga dapat menyediakan asrama kepada mahasiswanya dengan harga yang terjangkau, karena pada saat ini banyak mahasiswa dari luar daerah masih harus menyewa kamar/ kost dengan harga yang tidak terjangkau oleh mahasiswa.

6. Ditinjau dari faktor Lokasi, pihak yayasan harus mampu menyediakan security yang berada di sekitar lingkungan kampus untuk menajaga kelancaran lalu lintas, keamanan kendaraan yang diparkir, dan juga keamanan disekitar dimana mahasiswa menunggu angkutan umum.

\section{DAFTAR PUSTAKA}

Arikunto, Suharsini. 2003. Manajemen Penelitian, Cetakan Keenam, Rieneka Cipta, Jakarta.

Arikunto, 2006. Prosedur Penelitian Suatu Pendekatan Praktik. Edisi Revisi. Cetakan Kedelapan. Rineka Cipta : Jakarta.

Asnawi, 1993. Prilaku calon Mahasiswa Dalam Memasuki Perguruan Tinggi Swasta di Yogyakarta, Tesis, Pasca sarjana Universitas Gajah Mada, Yogyakarta.

Bucharai, Alma. 2011. Manajemen Pemasaran dan Pemasaran Jasa. Edisi Revisi. Cetakan Kesembilan. Alfabeta : Bandung. 
Departemen Pendidikan Nasional Republik Indonesia. 2003. Undang-Undang Republik Indonesia Nomor 20 Tahun 2003 Tentang Sistem Pendidikan Nasional. Jakarta : Medya Duta.

Ghozali, Imam. 2005. Aplikasi Analisis Multivariate Dengan Program SPSS . Badan Penerbit Universitas Diponegoro : Jakarta.

Hair, J.F., Anderson, R.E., Tatham, R.L. and Black, W.C. 2006. Multivariate Data Analysis, Sixth Edition, Prentice Hall International: UK.

Harahap, Novita. 2004. Analisis Faktor-Faktor Yang Mempengaruhi Keputusan Mahasiswa Dalam Menempuh Pendidikan Pada Politeknik LP3I Medan. Tesis Pascasarjana Universitas Sumatera Utara Medan.

Kotler, Philip. 2000. Marketing. Penerjemah : Herujati Purwoko, Jilid 1, Cetakan Ketiga, Jakarta : Erlangga.

Kotler, 2003. Principles of Marketing, Eight Edition. New York : Prenhalindo.

Kotler, dan Gary, Armstrong. 2004. Dasar-Dasar Pemasaran. Diterjemahkan oleh Alexander Sindoro, Jilid 1 Edisi Kesembilan. Jakarta : PT. Indeks

Kotler, Philip dan Keller. 2009. Manajemen Pemasaran (diterjemahkan Benjamin Molan). Edisi Ketiga Belas, Jilid 2, Penerbit Erlangga, Jakarta

Lamb, Charles W.Jr.,Joseph F.Hair,Jr. Dan Carl McDaniel. 2002. Marketing, $6^{\text {th }}$ Edition. South Western : Thompson Learning.

Lamb, 2001. Pemasaran. Alih Bahasa David Octarevia, Jilid 2 Edisi Pertama. Jakarta : Salemba Empat.

Lupiyoadi, Rambat. 2001. Manajemen Pemasaran Jasa : Teori dan Praktek, Edisi Pertama. Jakarta : Salemba Empat.

Lupiyoadi, Rambat, dan Hamdani. 2008. Manajemen Pemasaran Jasa, Edisi Kedua, Salemba Empat : Jakarta.

Nazir, Moh. 2003. Metode Penelitian. Jakarta : Ghalia Indonesia.

Santoso, Singgih, 2002, SPSS Statistik Multivariat, PT Alex Media Komputerindo, Jakarta.

Santoso, Singgih, 2001, Statistik Non Parametrik, Buku Latihan SPSS, PT Alex Media Komputerindo, Jakarta.

Setiadi, Nugroho J. 2003. Prilaku Konsumen : Konsep dan Implikasinya untuk Strategi dan Penelitian Pemasaran. Jakarta : Prenada Media. 
48 MODERNISASI, Volume 9, Nomor 1, Februari 2013

Schiffman, Leon G., dan Lesslie, Lazar Kanuk. 1994. Consumer Behavior. New Jersey : Prentice - Hall Inc.

Sugiyono., 2010. Metode Penelitian Kuantitatif Kualitatif dan R\&D, Penerbit Alfabeta 